\title{
Editorial
}

\section{Publicar en Enfermería Nefrológica}

Estamos asistiendo desde hace un tiempo, a un intento de publicar documentos en nuestra revista, y digo documentos, porque en absoluto se trata de artículos originales, ni de otro tipo de artículos que cumplan las Normas de Publicación de Enfermería Nefrológica; sino de documentos que no cumplen ninguno de los requisitos de publicación en revistas de ciencias de la salud, que suelen ser resúmenes de comunicaciones que se han enviado a congresos virtuales un poco ampliados, y que además, denotan una falta de respeto elemental a la Revista y a sus autores. Los autores de estos documentos no han dedicado ni media hora a leer una par de artículos de la Revista para darse cuenta del nivel metodológico que exige publicar en Enfermería Nefrológica y así aprender; y sobre todo, no han tenido en cuenta que para enviar a publicar un artículo a una revista científica, lo primero que hay que hacer es LEERSE LAS NORMAS DE PUBLICACIÓN de la revista en cuestión.

De otro lado, y aprovechando el título de la editorial, quisiera pedir disculpas a aquellos socios que se hayan podido sentir molestos por la tardanza en contestar a la valoración positiva o negativa de los artículos enviados para su publicación en nuestra Revista. Es cierto, que en determinadas ocasiones no se ha contestado en tiempo a la solicitud de publicación de algunos autores o autoras, que ante todo, son compañeras y compañeros. Ni que decir tiene, que han sido artículos que creíamos que no reunían los requisitos mínimos para ser publicados en Enfermería Nefrológica, puesto que siempre estamos escasos de trabajos que reúnan esos requisitos. No obstante, teníamos que haber contestado en tiempo y yo desde la responsabilidad de la dirección de la Revista, asumo este error. Exponer aquí excusas y motivar los porqués de que esto haya ocurrido, no vale la pena y hay que trabajar para que esto no vuelva a ocurrir, y sobre todo reitero mis disculpas a todas/os aquellas/os socios que se hayan sentido molestos por esta circunstancia.

Precisamente, y en la línea de que esto no vuelva a ocurrir, se han tomado decisiones que afectan a la composición del Comité Editorial de Enfermería Nefrológica y al proceso editorial en su conjunto. Estamos intentado corregir esos desajustes en este proceso para que todos los trabajos sean contestados en un plazo máximo de 3-4 semanas, afirmativa o negativamente; y a partir de ahí, aquellos artículos que han pasado a revisión por pares, podrán ser seguidos por sus autores en todo momento, para que sepan en qué situación se encuentra su artículo.

Estos cambios se empezarán a notar a partir del próximo número y espero que el esfuerzo de un grupo más amplio de voluntarios que van a colaborar con la revista, ayude a que todo el proceso editorial sea cada vez más sistemático. Sin embargo, hay que seguir insistiendo en que la principal colaboración para hacer más visible una revista científica, sigue siendo la de los autores que publican en la misma; y en ese sentido seguimos necesitando aumentar el número de artículos anuales que se reciben para ser publicados. Sin ellos, no hay revista. 
Por último, quiero dirigirme a todos los socios de la SEDEN, que quieren publicar en Enfermería Nefrológica. Lo primero que todos los socios deben tener claro es que la dirección y el proceso editorial de la Revista son totalmente independiente de la gestión de la Junta Directiva, en cuanto a criterios científicos y a la aplicación de las normas de publicación. La Junta Directiva no entra en el proceso de revisión por pares, y por supuesto no selecciona trabajos para publicar. Esto, aunque parezca una obviedad, no todo el mundo lo entiende pues a menudo las diferentes Juntas han ido recibiendo quejas en este sentido. Las quejas, en todo lo relacionado con Enfermería Nefrológica deben ser dirigidas a los responsables de la revista. Pero hay que querer entender cuál es el papel de los responsables de la Revista: en este momento nos encontramos inmersos en varios procesos de revisión por diferentes Bases de Datos, y en una de ellas en concreto, con la amenaza de sacarnos de la misma a final de año. Esto supone una gran responsabilidad y sobre todo, supone tener que tomar decisiones que en ocasiones no complacen a los autores, que suelen ser socios de la SEDEN, y que se sienten mal tratados. Por eso, y aunque en ocasiones no se entienda, estamos aquí para que se cumplan una serie de criterios, que no hemos inventado nosotros. Son unas reglas internacionales, por las que se rigen todas las revistas científicas, y que si queremos ser considerados como tales, tenemos que cumplir; y que si no cumplimos nos irán devolviendo nuevamente a lo que fue esta revista en sus orígenes.

Rodolfo Crespo Montero

Director de Enfermería Nefrológica

http://dx.doi.org/10.4321/S2254-288420170000200001 